\title{
The Norumbega Fault Zone, Maine: a mid- to shallow-level crustal section within a transcurrent shear zone
}

\author{
Mary S. Hubbard ${ }^{1}$, David P. West, Jr. ${ }^{1 *}$, Allan Ludman ${ }^{2}$, Charles V. Guidotti ${ }^{3}$ and Daniel R. Lux ${ }^{3}$ \\ 1 Department of Geological Sciences, University of Maine, Orono, Maine 04469, U.S.A. \\ ${ }^{2}$ Department of Geology, Queens College of the City University of New York, \\ Flushing, New York 11367, U.S.A. \\ ${ }^{3}$ Department of Geological Sciences, University of Maine, Orono, Maine 04469, U.S.A.
}

Date Received May 25, 1995

Date Accepted July 28, 1995

\begin{abstract}
From studies of structure, metamorphism, and geochronology we have evidence that the Norumbega Fault Zone represents a transition from mid- to shallow crustal levels in a dextral, transcurrent shear zone within the northern Appalachian Orogen. The Norumbega Fault Zone strikes parallel to the orogen (northeast-southwest), is $\sim 5$ to $30 \mathrm{~km}$ wide, and is characterized by distributed ductile dextral shear fabrics in the southwestern section with a transition to brittle fabrics toward the northeast. Within the zone of distributed shear, deformation is partitioned into local zones of very high strain. Upright, isoclinal folds are common in areas of high and low strain. Metamorphic grade decreases from amphibolite facies in the southwest to sub-greenschist facies in the northeast. ${ }^{40} \mathrm{Ar} /{ }^{39} \mathrm{Ar}$ mineral ages from recrystallized minerals in a high strain zone, regional cooling ages in areas of lower strain, and metamorphic textures are consistent with a polyphase history of deformation. We interpret a younging trend in ${ }^{40} \mathrm{Ar} /{ }^{39} \mathrm{Ar}$ cooling ages toward the northeast, together with the deformational fabrics and metamorphic features, to represent exhumation of the southwestern section of the Norumbega Fault Zone from mid-crustal levels during the polyphase history of this transcurrent zone. The Norumbega Fault Zone may therefore serve as a model for deformational processes at mid- to shallow crustal levels in active strike-slip systems.
\end{abstract}

Des études de la structure, du métamorphisme et de la géochronologie nous fournissent la preuve que la zone faillée de Norumbega représente une transition des niveaux crustaux moyens à des niveaux peu profonds dans une zone de cisaillement transversal dextrale à l'intérieur de la partie septentrionale de l'orogène appalachien. La zone faillée de Norumbega suit une direction parallèle à l'orogène (nord-est-sud-ouest); elle a cinq à $30 \mathrm{~km}$ de largeur; et elle est caractérisée par des structures cisaillées dextrales déformables se ramifiant dans la section sud-ouest avec une transition à des structures cassantes vers le nord-est. À l'intérieur de la zone de cisaillement ramifié, la déformation est divisée en zones locales de très forte contrainte. Les plis droits isoclinaux sont courants dans les secteurs de forte et faible contrainte. L'intensité du métamorphisme décroît d'un faciès à amphibolite dans le sud-ouest à un faciès secondaire de schistes verts dans le nord-est. Les périodes minérales ${ }^{40} \mathrm{Ar} /{ }^{39} \mathrm{Ar}$ des minéraux recristallisés dans une zone de forte contrainte, les périodes de refroidissement régional dans les secteurs de faible contrainte et les textures métamorphiques correspondent à une orogénèse polyphasée. Nous interprétons la tendance de rajeunissement dans les périodes de refroidissement ${ }^{40} \mathrm{Ar} /{ }^{39} \mathrm{Ar}$ vers le nord-est, de même que les textures de déformation et les caractéristiques métamorphiques, comme une exhumation de la section sud-ouest de la zone faillée de Norumbega depuis les niveaux crustaux moyens pendant l'histoire polyphasée de cette zone transversale. La zone faillée de Norumbega pourrait, par conséquent, servir de modèle pour les processus de déformation aux niveaux variant de moyens à peu profonds dans les systèmes à décrochement.

[Traduit par la rédaction]

\section{INTRODUCTION}

Strike-slip faults are major structural features in both ancient and active orogenic belts. The presence of strike-slip faults at plate margins or paleo-plate margins may be due to the fact that most major plate boundaries have or have had a component of movement that is boundary-parallel (Woodcock, 1986). Although the shallow-level structural characteristics of strikeslip faults can be relatively easily studied at the earth's surface

*Present address: Department of Geology, Lafayette College, Easton, Pennsylvania 18042, U.S.A. in active belts, it is necessary to identify strike-slip faults in exhumed orogens in order to study the structural characteristics at middle or deep crustal levels. Recent structural and petrologic study suggests that the Norumbega Fault Zone (NFZ), located in the northern Appalachian Orogen in the state of Maine, is an ancient strike-slip system that may have been differentially exhumed along its length such that a profile from mid- to shallow crustal levels is now exposed (Fig. 1). Though geochronologic data suggest that the NFZ may have had a prolonged or multi-stage late Paleozoic deformational history, structural analysis indicates that this deformation generally occurred at higher temperature in the southwestern section and lower 


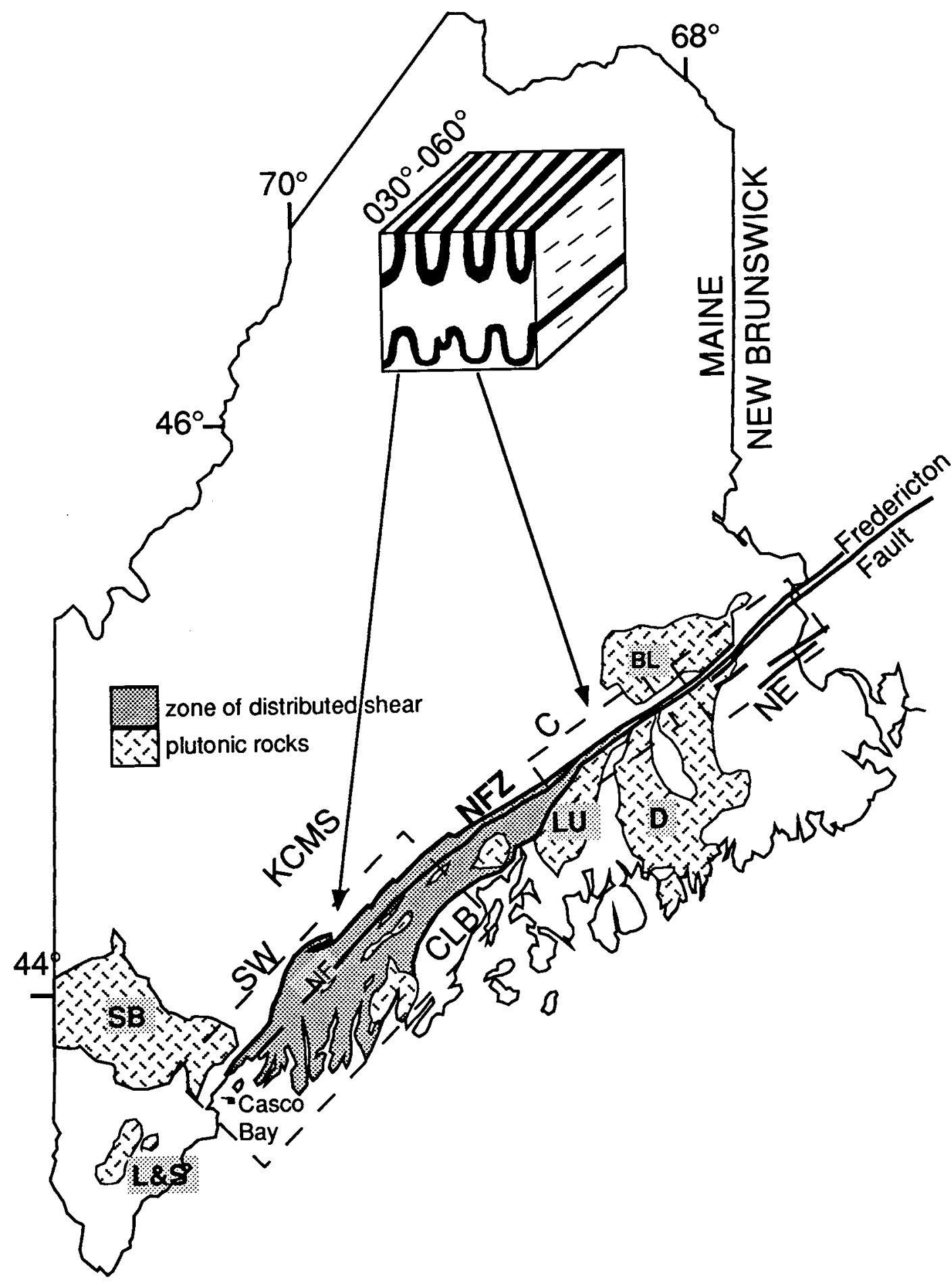

Fig. 1. Simplified tectonic map of the Norumbega Fault Zone (NFZ) in Maine and New Brunswick. The NFZ is characterized by a wide zone of distributed ductile shear with localized high strain zones in the southwestern section and discrete brittle faults in the northwestern section. Inset block diagram shows fold style typical in the southwestern and central sections. Dextral shear sense indicators are pervasive in map view. Subhorizontal stretching lineations are seen on foliation surfaces. SW = southwestern section of NFZ, C $=$ central section of NFZ, NE $=$ northeastem section of NFZ, NF = Norumbega Fault senso stricto (zone of high strain), KCMS = Kearsarge Central Maine Synclinorium, CLB = Coastal Lithotectonic Block, L\&S = Lyman and Saco Plutons, SB = Sebago Batholith, LU = Luceme Pluton, D = Dublois Pluton, BL = Bottle Lake Plutonic Complex. Modified from Osberg et al. (1985).

temperature in the northeastern section. Petrologic data support our conclusion that higher temperature conditions were also higher pressure conditions and therefore the southwestern section of the NFZ was deforming at deeper crustal levels than the northeastern section.

\section{GENERAL FEATURES OF THE Norumbega Fault Zone}

The Norumbega Fault Zone was first described by Stewart and Wones (1974) and Wones (1978) in south-central Maine. 
Subsequent field work (see below) has shown that this fault zone is generally wider than the zone first described and is continuous from western New Brunswick (mapped as the Fredericton fault) to southern Maine. The NFZ separates the Coastal Lithotectonic Block (CLB) to the southeast from the Kearsarge Central Maine Synclinorium (KCMS) to the northwest, but may include lithologies from both of these lithotectonic blocks.

The width of the NFZ varies dramatically in Maine, narrowing from $\sim 30 \mathrm{~km}$ in southwestern Maine (Swanson, 1994; West, 1993) to $\sim 5 \mathrm{~km}$ in its central section, and expanding to over $30 \mathrm{~km}$ in the northeast (Fig. 1). In addition to the original Norumbega fault (Stewart and Wones, 1974), the NFZ includes several previously mapped discrete faults in southern Maine, including the Nonesuch River, Flying Point, South Portland, Cape Elizabeth, and Phippsburg faults (Hussey, 1985) and several unnamed faults in eastern Maine.

The sense of movement for faults within the NFZ has been interpreted differently by different workers. Thrust-sense movement (Osberg et al., 1985), normal-sense movement (West et al., 1993), sinistral-sense movement (Kent and Opdyke, 1978) and dextral-sense movement (Hussey and Newberg, 1978) have all been suggested for different sections of the NFZ, based on criteria such as lithologic correlation, metamorphic discontinuities, paleomagnetic data, and geochronologic discontinuities. Some workers have also described the NFZ as a continental suture zone or terrane boundary (Kent and Opdyke, 1978; Zen, 1983; Williams and Hatcher, 1983). With the development of an understanding of kinematic indicators in the rock fabric, recent studies have provided evidence that dextral shear was pervasive from the Portland area to western New Brunswick (Swanson, 1992; Hubbard et al., 1991; Higgins, 1992; West, 1993; Orifici and Hubbard, in preparation; Ludman, 1994).

Constraints on the timing of dextral displacement along the NFZ have been provided by a combination of field and geochronological studies. These results suggest a protracted polyphase history of movement beginning in the Early to Middle Devonian and continuing well into the Permian. Ludman (1995, in press) in the eastern portions of the NFZ has clearly demonstrated that dextral deformation both pre-dated and post-dated intrusion of the Bottle Lake complex (380 Ma; Ayuso et al., 1984) and Deblois pluton (390 Ma; Loiselle, 1983). Similar relationships appear to exist in the vicinity of the Lucerne pluton (380 Ma; Zartman and Gallego, 1979) in the central portion of the NFZ. Additional constraints on the timing of movement along the easternmost portion of the NFZ are provided by mapped relationships in New Brunswick, where sedimentary rocks of Pennsylvanian age are offset by the Fredericton fault, the easternmost continuation of the NFZ (McLeod et al., 1994). The Fredericton fault is shown to die out in central New Brunswick, suggesting that movement may have ceased during Pennsylvanian time in this region.

Structural and geochronological studies (West, 1993; West and Hubbard, unpublished data) in the southwestern section of the NFZ also reveal a polyphase history of dextral shear deformation. In this region, a wide zone $(>20 \mathrm{~km})$ of heterogeneously distributed ductile shear fabrics are overprinted by a relatively narrow zone $(1 \mathrm{~km})$ of high-strain mylonitization and cataclasis.
Porphyroblast relationships in the wide zone of heterogeneous ductile shear indicate this deformation was largely syn- to postmetamorphic. ${ }^{40} \mathrm{Ar} /{ }^{39} \mathrm{Ar}$ hornblende ages of 368 to $381 \mathrm{Ma}$ from this region (West et al., 1988) indicate the latest amphibolite facies metamorphism was Middle Devonian; thus the shearing occurred during or after this time. ${ }^{40} \mathrm{Ar} /{ }^{39} \mathrm{Ar}$ mica ages of 320 to $360 \mathrm{Ma}$ from the region (West and Lux, 1993) indicate that cooling below $300^{\circ} \mathrm{C}$ occurred in the Early to Middle Carboniferous. As most of the ductile fabrics in the wide, distributed shear zone are interpreted to have formed at temperatures above $300^{\circ} \mathrm{C}$, this style of deformation most likely ceased by Middle Carboniferous time. Detailed ${ }^{40} \mathrm{Ar} /{ }^{39} \mathrm{Ar}$ studies of muscovite porphyroclasts $(290 \mathrm{Ma})$ in the overprinting high strain zones indicate that this dextral shear occurred in latest Carboniferous to earliest Permian time (West and Lux, 1993)

In summary, field and geochronological data indicate a complex and protracted history of movement along the NFZ. Studies from both the eastern and southwestern portions of the NFZ suggest that wide zones of largely ductile fabrics were the product of mainly Devonian dextral shear strain. Overprinting relatively narrow zones of high-strain mylonitization and cataclasis appear to have been the result of later (Carboniferous to Permian) dextral deformation. This change from mainly Devonian ductile deformation to later relatively brittle processes most likely reflects prolonged active dextral shear strain during regional exhumation (West and Hubbard, unpublished data).

\section{STRUCTURE AND KINEMATICS of the Norumbega Fault Zone}

The Norumbega Fault Zone is a remarkably linear feature in map view (Fig. 1). This linearity is due to the pervasive steeply dipping foliation characteristic of strike-slip zones. A variety of kinematic indicators support an interpretation of dextral shearsense for the NFZ. In the southwestern section of the fault zone ductile shear was distributed across the $\sim 30 \mathrm{~km}$ width of the zone. A well-defined, sub-horizontal mineral stretching lineation is oriented $030^{\circ}$ to $660^{\circ}$. Shear sense can be determined in this southwestern section by analysis of asymmetric porphyroclasts, mica fish, pressure shadows, shear bands, and asymmetric boudinage (Fig. 2). Various dextral indicators can be found within all lithologic units in the southwestern section, with the exception of some of the pegmatite pods. These pods, however, have an asymmetric shape themselves that is consistent with dextral shear along the northeast-striking NFZ.

The NFZ narrows to $\sim 5 \mathrm{~km}$ in the central section. The stretching lineation is sub-horizontal, trends $030^{\circ}$ to $060^{\circ}$ and in many places is seen as rodding of quartz. Kinematic indicators, including asymmetric clasts, shear bands, grain-shape preferred orientation of quartz, and asymmetric boudinage, are consistent with dextral shear.

In the northeastern section of the NFZ, ductile processes are limited to several very narrow ( $<1 \mathrm{~km}$ wide) zones; otherwise dextral slip was accommodated by brittle deformation along discrete fractures distributed across a zone $\sim 30 \mathrm{~km}$ wide. Locally, a Riedel geometry of fractures at outcrop scale suggests dextral sense of shear. These fractures include dominant northeast-striking fractures and east-striking synthetic fractures. Drag 

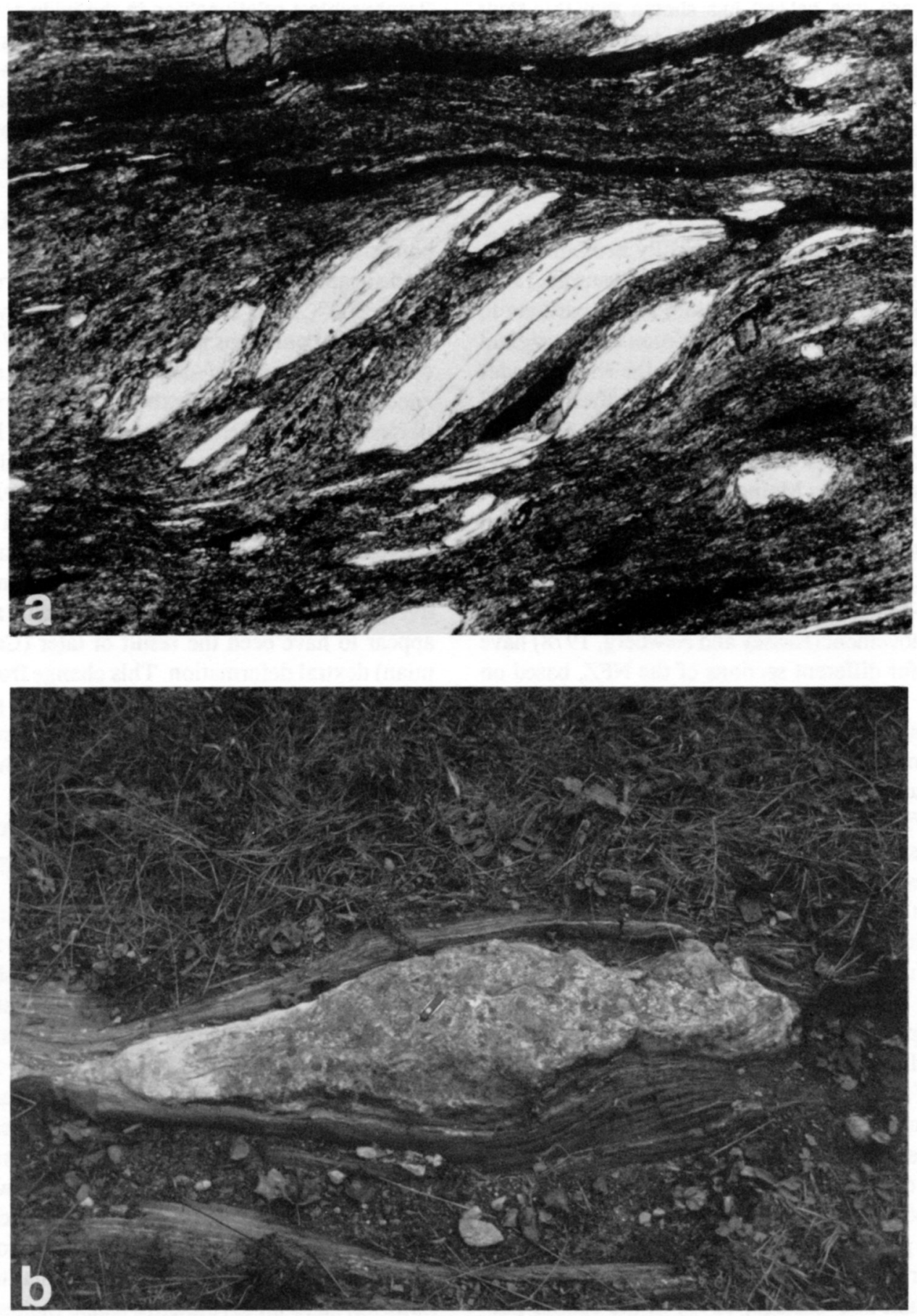

Fig. 2. Kinematic indicators from the NFZ. (a) Photomicrograph of mica fish from the southwestern section of the NFZ. Asymmetry consistent with dextral shear, NE on right. Long axis of photo is $2.5 \mathrm{~mm}$. Sample also contains recrystallized muscovite that yielded an $40 \mathrm{Ar} /{ }^{39} \mathrm{Ar}$ age of $290 \mathrm{Ma}$. (b) Assymetric pegmatite boudin from southwestern section of the NFZ. Assymetry indicates dextral shear. NE is on the right of the photo. Pocket knife provides a scale.

of bedding planes suggests dextral shear on both the northeaststriking and east-striking fracture systems. Some north-striking left-lateral fractures are suggestive of antithetic fractures in an overall right-lateral regime.

Localization of strain is variable along the length of the NFZ. In the wide southwestern section, dextral shear fabrics are penetrative and found across the entire width of the shear zone; some zones, however, exhibit remarkably higher strain (Hubbard et al., 1991; West, 1993; Swanson, 1994). Some of the high-strain zones are narrow zones and were previously mapped as faults or lithologic contacts. Swanson (1994) used quartz vein orientations to quantify strain in several areas of the southwestern section of the NFZ. He calculated minimum shear strain values as high as $\gamma=30$ for the high strain zones and $\gamma=5$ for areas of distributed shear. In the central section of the NFZ where the zone width is narrow, the strain is more homogeneous. The northeastern section, however, exhibits strain localization with deformation occurring largely in discrete brittle zones. 


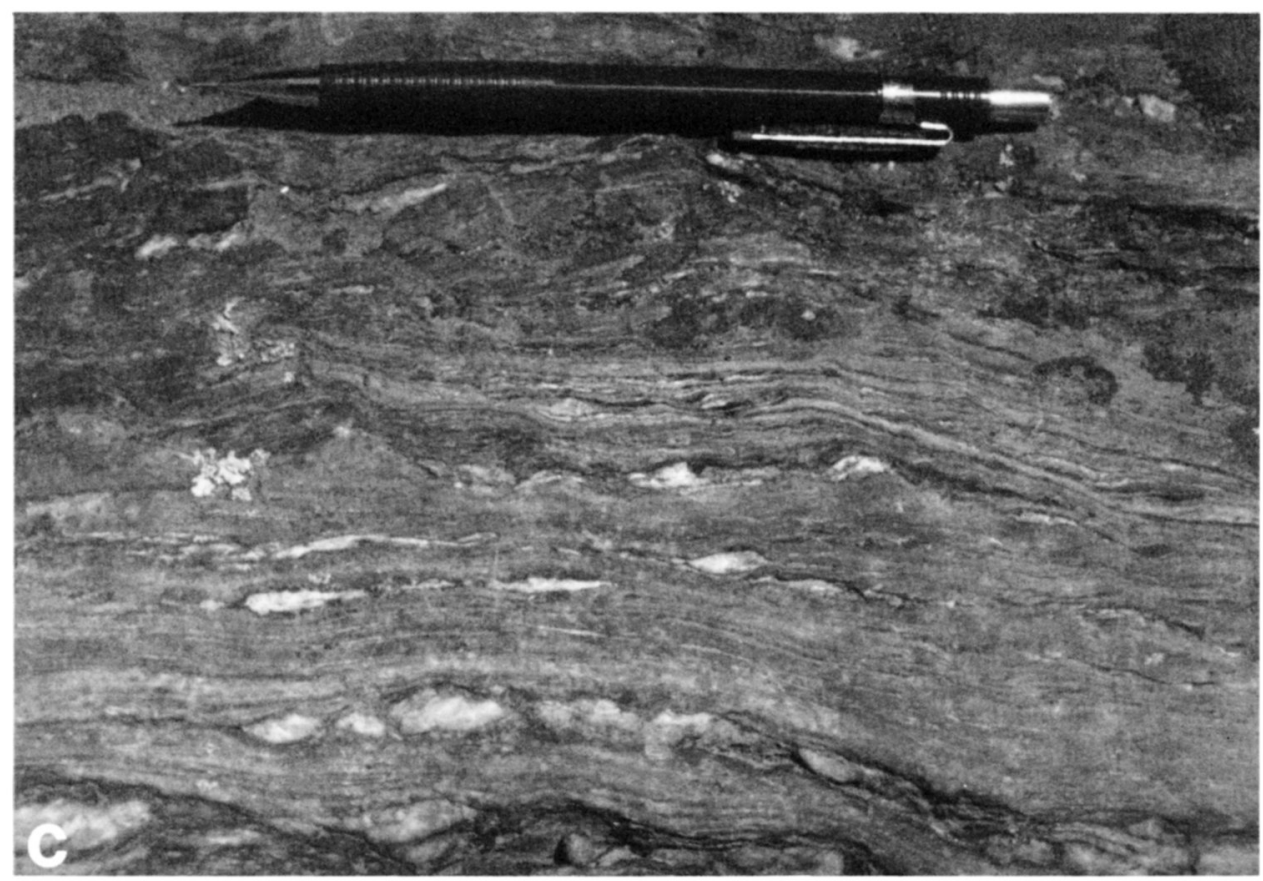

Fig. 2 Cont. (c) Shear bands and boudined quartz veins are consistent with dextral shear in the central section of the NFZ. NE is on the right of the photo.

Determination of the amount of displacerneit on the NFZ is hampered by the lack of displaced markers because lithologic contacts are generally parallel to the strike of the deformation zone. Using offset fragments of the Lucerne Pluton, Johnson and Wones (1984) estimated a minimum displacement value of $35 \mathrm{~km}$. Ludman (1995) estimated $\sim 50 \mathrm{~km}$ of displacement based on offset plutonic fragments in eastern Maine. Extrapolating local strain measurements discussed above in southern Maine, Swanson (1992) suggested that the total displacement on the NFZ could have been as much as $150 \mathrm{~km}$.

Folds are common along the length of the NFZ and are found in nearly all lithologies. Fold axes are dominantly horizontal, parallel-subparallel to the stretching direction and the overall strike $\left(030^{\circ}\right.$ to $\left.060^{\circ}\right)$ of the shear zone (Fig. 1, inset). Traditional interpretation of folds ascribe fold formation to purely compressional deformation. Simple shear fabrics indicative of dextral shear are found on both limbs of the folds and allow an alternative interpretation of fold formation during dextral strike-slip deformation (Hubbard, 1992; Swanson, 1992). Folds with axes parallel to transport direction, formed during simple shear deformation, have been documented in other orogens (Hansen, 1971; Mancktelow and Pavlis, 1994). These upright folds occur at the scale of a thin section, a hand sample, an outcrop, and a regional map. Though it is difficult to determine the amplitude of the map-scale folds, such folding could be responsible for the parallelism and repetition of initially horizontal/sub-horizontal lithologic contacts. Minor asymmetric folds with steep or vertical axes are also present along the fault zone and their " $\mathrm{z}$ "-shape is consistent with dextral shear.

\section{VARIATIONS IN STRUCTURAL LEVEL ALONG The Norumbega Fault Zone}

Changes in both deformational and metamorphic style along strike suggest that deformation occurred at deeper structural levels in the southwestern part of the NFZ than in the northeastern section. In the case of the deformational features, the change from dominantly ductile deformation to dominantly brittle deformation toward the northeast is consistent with an interpretation of a crustal profile. These ductile and brittle deformational fabrics, however, only provide a rigorous constraint regarding deformation being at higher temperatures in the southwest than the northeast section, but not necessarily at higher pressures.

Arguments for a crustal profile based on metamorphic style provide stronger evidence than structural features for deformation at higher pressure toward the southwest. These arguments range from indirect reasoning to direct observations regarding metamorphic conditions along and closely adjacent to the NFZ trace. In the former case, one can make an analogy with the study of DeYoreo et al. (1989), where it was shown that along the trace of the Kearsarge Central Maine Synclinorium there is a progressive exposure of structurally deeper levels to the southwest. The NFZ parallels the eastern boundary of the Kearsarge Central Maine Synclinorium essentially along the whole distance covered in the study of DeYoreo et al. (1989), thus suggestive that the NFZ occurred over a roughly similar range of depths $(<2-17 \mathrm{~km})$. 
Direct analysis of metamorphic assemblages provides another means of quantifying crustal level. Rocks in and around the southwestern section of the NFZ are clearly polymetamorphic. It has been generally accepted that syntectonic, Acadian-age ( Devonian) metamorphism was Buchan style or generally low pressure (Osberg et al., 1989). In the Casco Bay area, Lang and Dunn (1990) estimated metamorphic pressures of $\sim 250$ to $300 \mathrm{MPa}$. It is generally assumed that these pressures coincide with the timing of at least some of the distributed shear on the NFZ, but this has not been rigorously demonstrated.

Better evidence for deformation at mid-crustal levels during deformation along the southwestern section of the NFZ comes from the zone of more localized high-strain deformation and a zone of contact metamorphism close to the NFZ. The high-strain movement within the NFZ has been dated by West and Lux (1993) as occurring at $\sim 290 \mathrm{Ma}$. This deformational age is essentially the same as the newly proposed age ( $290 \mathrm{Ma}$; J.N. Aleinikoff, personal communication; P.B. Tomascak, personal communication) for the Sebago batholith. Though the Sebago batholith is not within the NFZ itself, it lies only 10 to $20 \mathrm{~km}$ to the west of the fault trace (Fig. 1). Thomson and Guidotti (1989) estimated pressures of 550 to $640 \mathrm{MPa}$ using mineral rim thermobarometry, and 625 to $750 \mathrm{MPa}$ using petrogenetic grids for the contact metamorphism induced by intrusion of the Sebago batholith on its southeastern side. These pressures translate to depths of 18 to $25 \mathrm{~km}$ and because of the proximity to the southwestern end of the NFZ (Fig. 1), the structural level of that portion of the shear zone should have been also 18 to $25 \mathrm{~km}$ deep at $290 \mathrm{Ma}$. Just 40 to $50 \mathrm{~km}$ northeast of the study area of Thomson and Guidotti (1989), Guidotti and Holdaway (1993) estimated pressures of $\sim 400 \mathrm{MPa}$ for pressures of late Carboniferous metamorphism, thus indicating that within the southwestern section of the NFZ there is evidence for decreasing pressures toward the northeast during the late Carboniferous.

In the central section of the NFZ, metamorphic and deformational conditions and thus structural level are more difficult to quantify. Three general rock types are exposed within the fault zone: (1) the Lucerne granite; (2) a garnet-chloritebearing gneissic rock; and (3) very fine-grained sedimentary/ metasedimentary ruck. The garnet-chlorite-bearing gneiss has a disequilibrium assemblage and the metamorphic minerals clearly pre-date deformation; therefore, the metamorphic rocks do not provide a good indicator of the pressure-temperature conditions during deformation. Deformation processes were ductile for quartz, but brittle for the feldspars (Fig. 3) so deformation conditions were likely to be in the range of middle greenschist facies (Simpson, 1985). The metasedimentary unit has a sufficiently fine grain size that it is not possible to determine petrographically whether or not it attained middle greenschist conditions.

In the northeastern section, the units affected by shear deformation include the Dublois and Bottle Lake plutonic rocks, generally non-metamorphic sedimentary rocks, and several local zones of biotite-grade metamorphic rocks. The biotite may reflect either local frictional heating due to fault movement, or possibly contact metamorphism due to adjacent plutonic rocks.
The majority of rocks in this northeastern section of the NFZ have never reached even lower greenschist facies, thus confirming that strike-slip deformation occurred at shallow structural levels in this region throughout its active history.

\section{Discussion AND CONClusion}

Structural, metamorphic, and geochronologic data from the Norumbega Fault Zone are indicative of dextral strike-slip deformation that occurred at higher pressure and temperature conditions in the southwestern section of the fault zone than in the northeastern section during the late Paleozoic. We interpret this difference in P-T conditions as a difference in structural level from southwest to northeast. This interpretation dictates that the southwestern section has experienced a greater amount of exhumation than the northeastern section. Pressure estimates (550-750 MPa) for metamorphic conditions in the southwestern section translate to a crustal depth of 18 to $25 \mathrm{~km}$ (Thomson and Guidotti, 1989). Rocks of the southwestern section are currently $\sim 270 \mathrm{~km}$ distant from rocks of the northeastern section, which means that in order to exhume the southwestern section from $\sim 20 \mathrm{~km}$ depth to its current location at the earth's surface would require a rotation of $\sim 4^{\circ}$ relative to the northeastern section of the fault zone, assuming a flat elevation profile. This small rotation would not significantly affect the regional orientations of structural elements such as linear or planar fabrics, or kinematic indicators. This amount of rotation has previously been suggested for exhumation in Maine based on the crustal levels of pluton emplacement (DeYoreo et al., 1989).

An alternative interpretation of observations along the NFZ is possible, but less likely. One could suggest that deformation occurred at different time intervals along strike so that the brittle deformation in the northeastern section of the fault zone was not coeval with ductile deformation in the southwest. Some temporal variability is certainly possible both along strike and across the width of the zone, but geochronologic constraints suggest that deformation was roughly coeval in the range of 380 to 290 Ma in the southwestern, central, and northeastern sections. Even if there was variation in the timing of deformation in the southwestern section relative to the central or northeastern sections, we still have strong evidence that the southwestern section deformed at crustal depths of $\sim 20 \mathrm{~km}$ whereas the northeastern section deformed at shallow crustal levels and, therefore, the NFZ provides an opportunity for the study of deformational behavior at various crustal levels on a strike-slip system.

In conclusion, the Norumbega Fault Zone has clearly played a role as a major strike-slip shear zone during the development of the northern Appalachian Orogen and due to variable exhumation, mid-crustal to shallow crustal levels are now exposed. This variation in crustal levels allows us to study the differences in deformational features resulting from strike-slip processes at mid- to shallow crustal levels. One of the major differences in structural style at mid-crustal levels is that deformation is distributed across a wide zone of ductile shear whereas at shallow crustal levels the deformation is partitioned into localized zones of brittle faulting. The width of the zone that includes these brittle faults is comparable to the width of the ductile zone $(\sim 30 \mathrm{~km})$. The southwestern section of the NFZ serves 


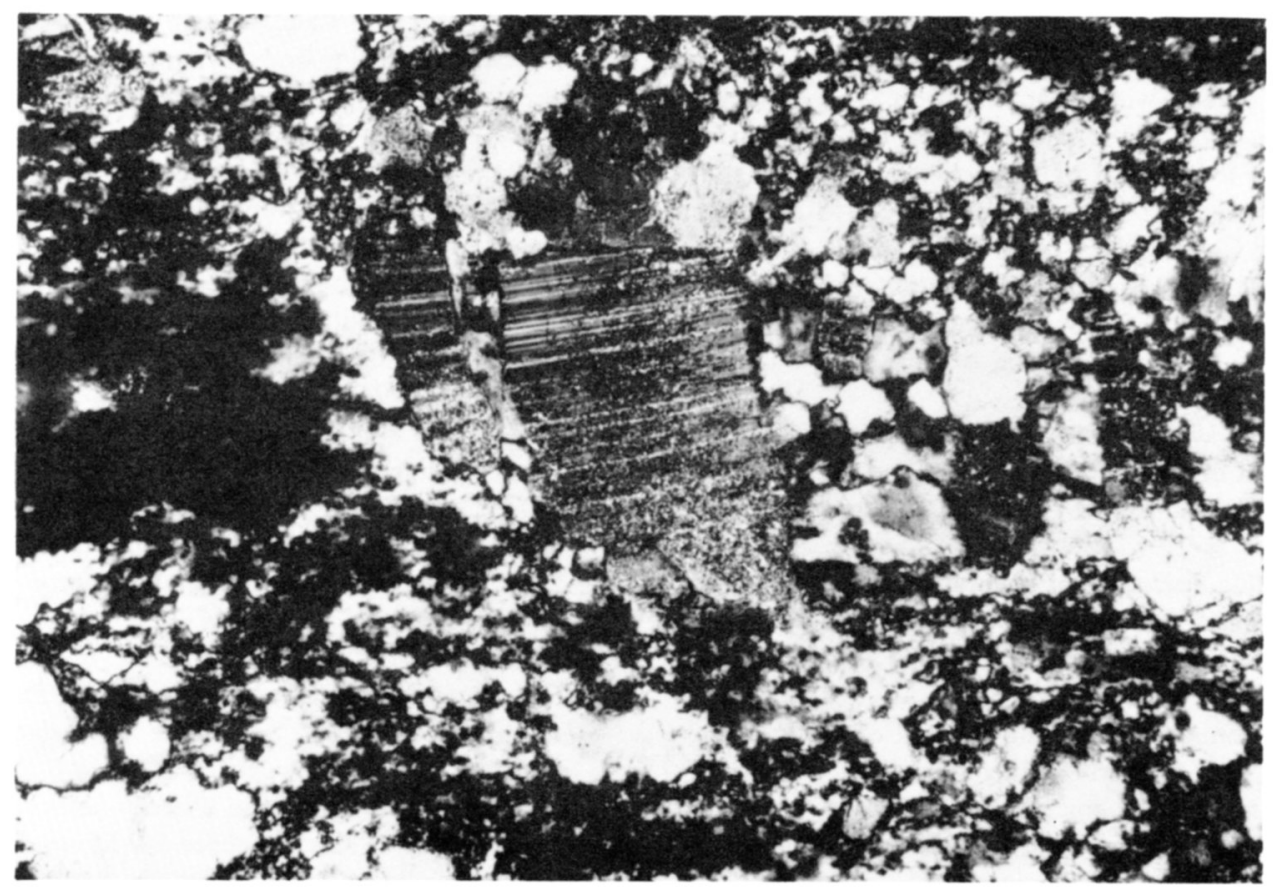

Fig. 3. Brittle/ductile fabric from central section of the NFZ. Quartz deformation was ductile while deformation of feldspar was brittle. Sample cut parallel to lineation, NE on right. Field of view is $6 \mathrm{~mm}$ long.

as a model for deformational features that may be forming at mid-crustal levels in active strike-slip systems such as the San Andreas. In the San Andreas system, active faults occur across a zone 50 to $100 \mathrm{~km}$ wide. Based on our observations of the $\mathrm{NFZ}$, one might expect a zone 50 to $100 \mathrm{~km}$ wide of distributed ductile shear at depths of $\sim 20 \mathrm{~km}$ within the San Andreas system. Upright folds are present along the NFZ at all crustal levels. Because upright folds occur along the San Andreas system at surficial levels, one might expect that folding processes are occurring at mid-crustal levels there as well. Recently a seismic reflector from mid-crustal levels on the San Andreas system below San Francisco Bay was interpreted as a horizontal detachment surface (Brocher et al., 1994). Though this hypothesis cannot be directly tested on the San Andreas system at present, one could use an ancient mid-crustal strike-slip system such as the NFZ to study possible geologic candidates for the horizontal reflector or other geophysically detected features. So perhaps the past can be the key to the present!

\section{ACKNOWLedgements}

The authors wish to thank Art Hussey, Mark Swanson, Spike Berry, Jim Orifici, Phil Osberg, Kost Pankiwskyj, Dave Stewart, Kip Hodges, Bob Marvinney, Kevin Higgins, Jon Yanasak, Wang Hui, and Doug Reusch for field trips and valuable discussions of Norumbega geology. We thank M. Meghan Miller, Les Fyffe, and an anonymous reviewer for comments on a draft of this manuscript. This work was supported by National Science Foundation grant EAR-9218833.
Ayuso, R.A., ARTh, J.G., SinhA, A.K., and Wones, D.R. 1984. Comparative geochronology in the reversely zoned plutons of the Bottle Lake complex, Maine: $\mathrm{U}-\mathrm{Pb}$ on zircons and $\mathrm{Rb}-\mathrm{Sr}$ on whole rocks. Contributions to Mineralogy and Petrology, 88, pp. 113-125.

Brocher, T.M., McCarthy, J., Hart, P.E., Holbrook, W.S., Furlong, K.P., McEvilly, T.V., Hole, J.A., and KLEMPERER, S.L. 1994. Seismic evidence for a lower-crustal detachment beneath San Francisco Bay, California. Science, 265, pp. 1436-1439.

DeYoreo, J.J., Lux, D.R., Guidotti, C.V., DeCker, E.R., and Osberg, P.H. 1989. The Acadian thermal history of western Maine. Journal of Metamorphic Geology, 7, pp. 169-190.

Gundott, C.V. and Holdaway, M.J. 1993. Petrology and field relations of successive metamorphic events in pelites of west-central Maine. In Field trip guidebook for the northeastern United States. Edited by J.T. Cheney and J.C. Hepburn. 1993 Boston GSA, 1, pp. L1L26.

Hansen, E. 1971. Strain facies. New York, Springer-Verlag, 207 p.

Higgrns, K. 1992. The Norumbega Fault Zone, Great Pond, Maine. M.Sc. thesis, University of Maine, Orono, Maine, $94 \mathrm{p}$.

HubBarD, M.S. 1992. Fold development in a strike-slip shear zone, the Norumbega Fault system, Maine. EOS, 73:43, p. 534.

Hubbard, M.S., West, D.P., JR., Lux, D.R., OrIfice, J., Guidotti, C.V., Higans, K., and Yanasak, J. 1991. Major dextral strike-slip deformation in the northern Appalachians: the Norumbega Fault Zone, Maine. Geological Society of America, Abstracts with Programs, 23:5, p. A311.

Hussey, A.M., II. 1985. The bedrock geology of the Bath and Portland 2 degree mapsheet, Maine. Maine Geological Survey, Open-File No. 85-87, 82 p.

Hussey, A.M., II and Newberg, D.W. 1978. Major faulting in the Merrimack Synclinorium between Hollis, New Hampshire and Biddeford, Maine. Geological Society of America, Abstracts with Programs, 10, p. 48. 
JOHNSON, T.D. and WonEs, D.R. 1984. Sense and mode of shearing along the Norumbega fault zone, eastern Maine. Geological Society of America, Abstracts with Programs, 16, p. 27.

KENT, D.V. and OPDYKe, N.D. 1978. Paleomagnetism of the Catskill red beds; evidence for motion of the coastal New EnglandCanakian maritime region relative to cratonic North America. Journal Geophysical Research, 83, pp. 4441-4450.

LANG, H.M. and DunN, G.R. 1990. Sequential porphyroblast growth during deformation in a low-pressure metamorphic terrain, Orrs Island-Harpswell Neck, Maine. Journal of Metamorphic Geology, 8, pp. 199-216.

Loiselle, M., Erikkson, S., Wones, D.R., and Sinha, A.K. 1983. Timing and emplacement of post-Acadian plutons in central and eastern Maine. Geological Society of America, Abstracts with Programs, 15, p. 187.

LUDMAN, A. 1994. Multiple displacement history and nature of deformation of the Kellyland Fault (Norumbega Fault Zone), eastern Maine. Geological Society of America, Abstracts with Programs, 26:3, p. 57.

1995. Strain partitioning, timing, and amount of offset in the Norumbega Fault Zone, eastern Maine. Geological Society of America, Abstracts with Programs, 27:1, p. 65.

— In press. The Kellyland fault zone: Model for supracrustal evolution of the Norumbega fault zone in metasedimentary rocks, eastern Maine and southwestern New Brunswick. Journal of Structural Geology.

Mancktelow, N.S. and Pavlis, T.L. 1994. Fold-fault relationships in low-angle detachment systems. Tectonics, 13, pp. 668-685.

McLeod, M.J., Johnson, S.C., and Rutenberg, A.A. 1994. Geological map of southeastern New Brunswick. New Brunswick Department of Natural Resources and Energy, Map NR-5 (1:250 000).

Osberg, P.H., Hussey, A.M., IV., and Boone, G.M. 1985. Bedrock geologic map of Maine. Maine Geological Survey, scale 1:500,000.

Osberg, P.H., Turl, J.F., Robinson, P., Hon, R., and Butler, J.R. 1989. The Acadian orogen. In The Geology of North America, Volume F-2 The Appalachian-Ouachita Orogen in the United States. Edited by R.D. Hatcher et al. Geological Society of America, Boulder, Colorado, pp. 179-232.

Simpson, C. 1985. Deformation of granitic rocks across the brittle-ductile transition. Joumal of Structural Geology, 7, pp. 503-511.

Stewart, D.B. and Wones, D.R. 1974. Bedrock geology of northern Penobscot Bay area. In NEIGC guidebook for field trips in east central and north central Maine. Edited by P.H. Osberg, pp. 223 239.
SWANson, M.T. 1992. Late Acadian-Alleghenian transpressional deformation: evidence from asymmetric boudinage in the Casco Bay area, coastal Maine. Journal of Structural Geology, 14:3, pp. 323342.

1994. Minimum dextral shear strain estimates in the Casco Bay area of coastal Maine from vein reorientation and elongation. Geological Society of America, Abstracts with Programs, 26:3, p. 75.

Thomson, J.A. and Gundotri, C.V. 1989. Carboniferous Barrovian metamorphism in southern Maine. Maine Geological Survey, Studies of Maine Geology, 3, pp. 35-51.

WeST, D.P., JR. 1993. Nature, timing, and extent of dextral shear deformation in south-central Maine. $\mathrm{PhD}$ thesis, University of Maine, Orono, Maine, 228 p.

West, D.P. JR. and Lux, D.R. 1993. Dating mylonitic deformation by the ${ }^{40} \mathrm{Ar}-{ }^{39} \mathrm{Ar}$ method: an example from the Norumbega Fault Zone, Maine. Earth and Planetary Science Letters, 120, pp. 221237.

West, D.P., Lux, D.R., and Hussey, A.M., II. $1988 .{ }^{40} \mathrm{Ar} /{ }^{39} \mathrm{Ar}$ mineral ages from southwestern Maine: Evidence for Late Paleozoic metamorphism. Maritime Sediments and Atlantic Geology, 24, pp. 225-239.

— 1993. Contrasting thermal histories across the Flying Point fault, southwestern Maine: evidence for Mesozoic displacement. Geological Society of America Bulletin, 105, pp. 1478-1490.

Williams, H. and Hatcher, R.D., JR. 1983. Suspect terranes: a new look at the Appalachian orogen. In Contributions to the tectonics and geophysics of mountain chains. Edited by R.D. Hatcher, Jr., $\mathrm{H}$. Williams and I. Zietz. Geological Society of America, Memoir 158 , pp. 33-54.

WonEs, D.R. 1978. Norumbega fault zone, Maine. U.S. Geological Survey Summary of Technical Reports VIII, National Earthquake Hazards Reduction Program, pp. 108-111.

Woodcock, N.H. 1986. The role of strike-slip fault systems at plate boundaries. Philosophical Transactions of the Royal Society of London, A317, pp. 13-29.

ZarTman, R.E. and Gallego, M.D. 1979. Radiometric ages: Compilation B, U.S. Geological Survey. In Isochron West. Edited by R.F. Marvin and S.W. Dobson. The Bulletin of Isotopic Geochronology, 26, pp. 18-19.

ZEN, E. 1983. Exotic terranes in the New England Appalachians, limits, candidates, and ages. A speculative essay. In Contributions to the tectonics and geophysics of mountain chains. Edited by R.D. Hatcher, Jr., H. Williams and I. Zietz. Geological Society of America, Memoir 158, pp. 55-81. 